\title{
A COUNTY SEAT LOST AND RECOVERED
}

\section{By Remley J. GLass}

The county seat of Cerro Gordo county, Iowa, had been located at Mason City, when the county was organized on August 7, 1855.

In December of 1856 Thomas Drummond, Marcus Tuttle, Silas Card and I. W. Card presented a petition to the Iowa legislature asking the appointment of three commissioners to relocate the county seat. Their petition was approved and in January, 1857, Stephen $H$. Henderson of Mitchell county, James Taggart and George McCoy of Benton county were appointed commissioners to name and locate the seat of justice of Cerro Gordo county. (Sixth G. A. Chapter 97.)

The commissioners were to meet at "Cedar Lake Village" in said county on the first Monday in February or within ninety days thereafter and carry out their duties.

These commissioners met at Clear Lake on April 29, 1857, and after being sworn in by I. W. Card, a pioneer Cerro Gordo county attorney, they determined that Livonia, a locality just north-east of Clear Lake, was the proper place for the county seat.

On June 11, 1857, Elon A. Tuttle and wife, and Marcus Tuttle and wife filed plat of Livonia, laid out on a part of Northwest Quarter of Northeast Quarter in Eighteen and Southwest Quarter of Southeast Quarter of Seven in 96-22, Lake township.

In the surveyor's notes the spelling of the name is "Lavonia."

During the following summer a court house, costing $\$ 1,000.00$ was built at Livonia. Some of the county records were moved to the new seat of justice that fall and on February 1, 1858, the county court, after convening at Mason City, adjourned to the new court house. 
A petition was presented to this session of the county court seeking the removal of the county seat to Mason City. An election was held that spring and Mason City won. Mason City-155 and Livonia-48. The records were thereupon returned to Mason City, which has since continued as the county seat.

\section{Cerro Gordo County's Abandoned Towns}

Shortly after the railroads came to Cerro Gordo county, and long before the days of paved highways and rapid transportation, a number of stations were located and sidings constructed to facilitate shipment of grain and live stock. The owners of land adjacent to each one of these were receptive to the idea of the development of a village or town in the vicinity, with resultant profitable lot sales.

Freeman Station-Freeman on the old Iowa Central, now the Minneapolis and St. Louis, was such a one, located on Northwest Quarter of Northwest Quarter of 22-97-20 in Lime Creek township. It was named after S. J. Freeman on whose farm the station was built. The station was established shortly after the old Iowa Central was built. A store was erected and some of the adjacent farms sub-divided into smaller tracts upon which homes and garden spots were established. Changing conditions resulted in the elimination of this young city and all that remains is the red painted railroad station, with broken windows and open doors.

CAMERoN Siding-South of Mason City on the old Iowa Central was located Cameron siding in Section 3-95-20, in Bath township. Its name came from W. W. Cameron who operated the grain elevator in Mason City on the Iowa Central track. A grain elevator and stockyards were erected and still are of service to the farmers in the surrounding community.

FLINT-In 1907-8 when the St. Paul and Kansas Short Line, now the Rock Island Line, was constructed, two 
little stations, Flint and Hurley, were built to aid in handling shipments of grain and live stock. The railroad purchased sufficient land from the Broers family located in the Southwest Quarter of 8-95-20, Bath township, for a station, elevator and stockyards. No one has been able to tell me for whom this village of Flint was named. Now it is entirely abandoned, the depot itself having been sold a few years ago.

HURLEY-A little farther south in Bath township on the Rock Island Line, the unincorporated village of Hurley was located on the Southwest Quarter of 20-95-20 which then formed a part of the old James McLaughlin farm. Its name came from that of the Brown-Hurley Company of Des Moines, important patrons of the road according to information furnished by Harlan McMillan, then and for many years thereafter an employee of the Rock Island railway. A station, store, elevator, stockyards and a few homes were built. A few years ago the Farmers Elevator at Hurley burned and today only a few of the buildings remain.

Traction PARK-The Brice and Ong Land Company platted Traction Park about half way between Mason City and Clear Lake on August 20, 1897. It is located on the South Half of Northwest Quarter in 13-96-21. The plat was filed on August 30, 1897, and appears on Plat Book One, Page 363. The surveyor who had charge of this work was Chester T. Dike, who was later in the employ of the Chicago Northwestern Railroad Company, being Vice President and Chief Engineer at the time of his retirement:

EMERY-When the question of a post office in this community came up it was named Emery for G. A. Emery who had been interested with $\mathrm{Mr}$. Brice and $\mathrm{Mr}$. Ong in the development of the Mason City and Clear Lake Electric Iine. A number of houses were built at Emery or Traction Park together with a large power plant and shops for the electric line, only in case of emergency. 
At the time the plat was laid out, lots were sold and houses constructed, many of which were financed through the Iowa Central Building and Loan Association, which I am informed, took quite a beating when the development of Emery ended.

Today nearly all the homes which were located there have been removed and the power plant is used only in emergencies. The early organizers of this village had great plans for its development, claiming that because of its more central location it was the proper place for the county seat.

\section{VALUE OF A COUNTY HISTORICAL UNIT}

Interest in history, as in all other activities, is subject to fluctuation. There are circumstances and occasions which arouse general interest in it and call for organized leadership. There are times when other interests are so paramount that the records of the past reecive little attention. There are other times in which there seems to be nothing at all doing; times in which the community sinks into a lethargy of boresome routine existence. If this latter condition becomes chronic, the community loses all impetus and pulls its people downward and backward, both as regards its history and perhaps everything else.

It is safe to say that there is no community or county which does not have some means and some occasion for interest in its past and hope for its future. The advantages to the people of a county and to the county of having an organized group of citizens interested in the study, preservation, and writing of local history are such that all unorganized counties should proceed at once to form local societies. A well organized historical group may serve as a center in which to keep alive interest in even ordinary times and to furnish leadership for productive activity in livelier times.

The present calls for activity in every line in every community-in local matters no less than in national 
Copyright of Annals of Iowa is the property of State of Iowa, by \& through the State Historical Society of Iowa and its content may not be copied or emailed to multiple sites or posted to a listserv without the copyright holder's express written permission. However, users may print, download, or email articles for individual use. 